\title{
DOI: https://doi.org/10.35546/kntu2308-8834/2020.1.24
}

УДК 343.8/344

\section{Проніна Оксана Володимирівна}

доцент кафедри державного

управління і місцевого самоврядування

Херсонського національного технічного університету кандидат наук $з$ державного управління, доцент

\section{УПРАВЛІННЯ ОРЕНДНИМИ ЗЕМЛЯМИ СІЛЬСЬКОГОСПОДАРСЬКОГО ПРИЗНАЧЕННЯ В УМОВАХ ДЕЦЕНТРАЛІЗАЦІЇ В УКРАЇНІ}

У статті розглядаються основні принципи управління земельними ресурсами в умовах децентралізації державного управління та посилення автономії органів місиевого самоврядування, їх розвитку на основі управління земельними ресурсами, які містяться за межами населених пунктів.

Доведено, щчо для територіальних громад земельні ресурси мають иінність з двох основних причин - як складова навколишнього середовища та місиевого проживання людини та як економічний ресурс для організації сільськогосподарського виробництва.

Досліджено особливості земельних ресурсів, щзо визначають державну політику у сфері земельних відносин. Такими особливостями є просторові обмеження, природність та вичерпність ресурсу, сталість розташування, здатність погіршувати властивості трунту в разі неправильного управління земельними ділянками.

Зазначено, щуо питання децентралізащії повноважень відображені в Концепиіі реформування місцевого самоврядування та територіальної організації в Україні, щуо пов'язано з тим, щьо основна частина земельних ресурсів має бути передана в розпорядження органів місцевого самоврядування, державних органів та об'єднаних територіальних громад, а інша частина - має відпускатися за державними нормами. При изьому державний контроль за використанням земельних ресурсів має здійснювати орган Держгеокадастру.

Новостворені об'єднані територіальні громади отримали потужні економічні ресурси для свого розвитку, проте питання ефективного та раціонального використання земельних ресурсів ще недостатньо врегульовано.

Ключові слова: земельні ресурси, землі сільськогосподарського призначення, територіальна громада, дещентралізачія, державне управління.

Постановка проблеми в загальному вигляді. Земля завжди була ключовим ресурсом у будь-якій країні світу, і не тільки аграрної. Це той ресурс, без якого не може існувати жодна країна. Тому в кожній державі існує власне ставлення до землі та вироблено унікальні засади державного управління нею. Основною метою державного управління земельними 
ресурсами у провідних розвинутих країнах є дбайливе ставлення до землі та збереження іiі в належному стані для майбутніх поколінь.

Для України ці питання є важливими, оскільки земля тривалий час не розглядалася як чинник економічного зростання та добробуту громадян, а основні засади державної політики були спрямовані на недопущення продажу землі. Натомість земля як об’єкт державного регулювання залишається недостатньо визначеною у правовому змісті та відповідно не вироблено засад з ефективного управління у сфері земельних відносин.

Для України земельні ресурси, на використання яких формується близько 95\% обсягу продовольчого фонду та 2/3 фонду товарів споживання, є первинним чинником організації виробництва та розвитку економіки. Варто зазначити, що частка земельних ресурсів у складі продуктивних сил країни становить понад 40\%, а в ресурсній забезпеченості соціально-економічного розвитку України земля становить майже $45 \%$.

Аналіз останніх досліджень і публікацій. Вагомий внесок у розроблення окремих аспектів державного управління земельними ресурсами зробили В. Андрєйцев, М. Болдуєв, А. Варламов, С. Волков, М. Головатюк, Ю. Гуцуляк, В. Срмоленко, О. Мордвінов, А. Мартин, А. Мерзляк, А. Статівка, П. Саблук, М. Ступень, М. Федоров, О. Шапоренко, Г. Шарий, А. Шеремет, А. Юрченко та ін. Незважаючи на значну кількість публікацій, вітчизняною наукою недостатньо досліджено питання щодо управління землями сільськогосподарського призначення в процесі децентралізації в Україні, а також удосконалення шляхів та механізмів їі практичної реалізації.

Формулювання цілей статті. Мета статті - дослідити та узагальнити наукові уявлення щодо ефективності управління орендованими землями сільськогосподарського призначення в умовах децентралізації в Україні.

Виклад основного матеріалу. Питання децентралізації повноважень відбито в Концепції реформування місцевого самоврядування та територіальної організації влади в Україні, схваленій Розпорядженням 
Кабінету Міністрів України № 333р від 1 квітня 2014 року. У ній зазначається, що однією 3 нагальних проблем розвитку місцевого самоврядування є подолання його відстороненості від вирішення питань у сфері земельних відносин. Для розв'язання такої проблеми пропонується надання органам місцевого самоврядування базового рівня повноважень у вирішенні питань забудови (відведення земельних ділянок, надання дозволів на будівництво, прийняття в експлуатацію будівель), визначення матеріальною основою місцевого самоврядування майна, зокрема землі, що перебуває у власності територіальних громад сіл, селищ, міст (комунальній власності), та належної бази оподаткування, а також надання територіальним громадам права розпоряджатися земельними ресурсами в межах своєї території. Сьогодні питання земельних відносин контролюється органами місцевого самоврядування лише в межах населених пунктів (близько 4\% території України). Цю систему потрібно змінити, передавши основну частину земельних ресурсів у розпорядження саме органам місцевого самоврядування, спроможним територіальним громадам, а іншу частину залишити за державою. Роль держави насамперед полягатиме в забезпеченні контролю за раціональним використанням земель сільськогосподарського призначення.

Особливо актуально ці питання постали в контексті розвитку місцевого самоврядування в нашій країні i, починаючи з 2014 року, набули нового імпульсу в рамках децентралізації та посилення реальної здатності територіальних громад розпоряджатися власним майном i ресурсами, основними з яких є саме земельні. Ця проблема постає в умовах ринкової економіки, коли законодавчо закріплюються різні форми власності на землю і господарювання на ній. Громадянам України було передано у власність мільйони гектарів земель для розширення особистих селянських господарств, організації селянських (фермерських) господарств, значні площі для будівництва житла, ведення садівництва і городництва тощо [2]. Збільшення 
чисельності суб'єктів господарювання на землі ініціювало розширення кола учасників земельних відносин, а реформа децентралізації фактично пов'язана 3 діяльністю ще одного важливого суб’єкта управління на місцевому рівні об’єднаної територіальної громади.

Для територіальних громад земельні ресурси важливі з двох основних причин - як компонент навколишнього середовища i місце проживання громадян, і як економічний ресурс: це землі сільськогосподарського та несільськогосподарського призначення, які можна використовувати для організації виробництва або здавання в оренду. Зважаючи, що як і будь-який інший економічний ресурс земля $є$ вичерпним ресурсом, цей принцип покладається в основу державної політики регулювання земельних відносин у більшості зарубіжних країн. Тому державне управління земельними відносинами та ресурсами грунтується також на принципах як раціонального та науково обгрунтованого використання землі з урахуванням економічного задоволення потреб населення, так і збереження належного стану земельних ресурсів для розвитку країни в майбутньому [3].

Розвиток теорії управління земельними ресурсами пов'язаний з теорією управління загалом і в історичну епоху земельні питання закладалися в теорію управління державою. Найбільш широким є тлумачення управління як соціальної категорії, пов’язаної з потребою встановлення й підтримки порядку в соціумі. В економічній сфері управління розглядається як потреба раціональної організації виробництва й оптимального перерозподілу обмежених наявних ресурсів [4].

Як об’єкт управління земельні ресурси мають певні особливості й відрізняються від інших економічних ресурсів держави за такими показниками:

- просторова обмеженість (територією країни);

- природний ресурс;

- вичерпний ресурс; 
- постійність місця розташування;

- властивість до погіршення в разі нераціонального та безгосподарського використання;

- можливість відтворення родючості та продуктивності землі та ін.

Ці особливості також визначають державну політику у сфері земельних відносин і безпосередньо мають бути пов'язані з переданням земельних ресурсів у власність територіальних громад. Наскільки ефективно буде здійснюватися управління земельними ресурсами, настільки це відіб'ється на показниках соціально-економічного розвитку конкретної територіальної громади та держави загалом.

В Україні вже була спроба врегулювати земельні відносини і зробити цей процес більш прозорим, проте земельна реформа не дала бажаних результатів і посилила руйнацію земельного регулювання, плутанину в земельних відносинах та повноваженнях суб’єктів господарювання [5]. Головними причинами такої ситуації є втрата державою функцій управління земельними ресурсами й відсутність єдиної земельної політики та дієвих важелів державного регулювання. Наприклад, розпорядники земель не мають мотивації щодо наповнення місцевих бюджетів, їх орендна плата часто $є$ неадекватною і значно заниженою.

Коли набрав чинності Земельний кодекс, права органів місцевого самоврядування в земельній сфері стали суттєво обмежені [1]. Місцеві ради розпоряджалися трохи більше $12 \%$ всієї території держави, оскільки землі за межами населених пунктів, як правило, не входили до сфери відання громад; передання землі здійснювалася хаотично без урахування інтересів громад i перспективних планів територій.

Щодо нормативно-правових засад, то основними нормативноправовими актами з регулювання земельних відносин та децентралізації під час створення ОТГ є Конституція України [6], Концепція реформування місцевого самоврядування та територіальної організації влади в Україні [12], 
закони України «Про добровільне об’єднання територіальних громад» [8], «Про місцеве самоврядування в Україні» [9] та ін. У контексті децентралізації було внесено зміни до Бюджетного та Податкового кодексів України.

Безпосередньо питання децентралізації повноважень відбито в Концепції реформування місцевого самоврядування та територіальної організації влади в Україні, схваленій Розпорядженням Кабінету Міністрів України № 333р від 1 квітня 2014 р. [7]. У Концепції зазначається, що однією з нагальних проблем розвитку місцевого самоврядування $є$ подолання його відсторонення у вирішенні питань у сфері земельних відносин.

Регулювання земельних відносин як об’єкта контролю з боку органів місцевого самоврядування здійснюється в межах населених пунктів i становить лише 4\% території України, а 96\% - це земельні ресурси, які перебували в розпорядженні органів виконавчої влади [10]. Таким чином, реформування та децентралізація влади пов'язані зі зміною системи регулювання земельних відносин, виробленням принципово нових підходів в унормуванні діяльності 3 вирішення власника землі в Україні. У ході реформи було вирішено передати основну частину земельних ресурсів у розпорядження саме органам місцевого самоврядування й об'єднаним територіальним громадам, а іншу частину - залишити за державою. Такий розподіл було здійснено в такій пропорції: $84 \%$ земельних ресурсів передати в розпорядження територіальних громад, 16\% - під контролем Кабінету Міністрів України (землі дна територіального моря; землі під великими та малими річками; землі в зоні відчуження; землі природо-заповідного фонду; землі лісового фонду; землі оборони) [10].

Водночас з реформами значно має змінитися роль держави в напряму більшої підконтрольності та відповідальності. На сьогодні ці засади суворого контролю та відповідальності за неналежне використання земельних ресурсів 
фактично відсутні. Не містяться вони і в проектах законів щодо подальшого реформування місцевого самоврядування.

Розроблено певний законопроект, який має надати змогу зробити важливий крок і передати повноваження органам місцевого самоврядування 3 розпорядження землями державної власності 3 одночасним посиленням державного контролю над використанням та охороною земель.

Водночас основним суб’єктом, який буде здійснювати державний контроль за використанням земельних ресурсів, $\epsilon$ Держгеокадастр. Децентралізація земельних відносин передбачає передання права розпорядження землями громадам, власність на землі перейде до об'єднаних громад, Держгеокадастр буде здійснювати лише контроль над використанням землі [11].

Урахування запропонованих підходів під час формування адміністративно-територіальних одиниць базового рівня при вдосконаленні земельного законодавства могло 6 надати змогу спростити відповідні адміністративні процедури та мінімізувати кількість потенційних конфліктів у процесі управління територіями та розвитком територіальних громад, натомість у практичному вимірі ці конфлікти тільки посилилися та потребують негайного вирішення в нормативному забезпеченні [11].

За таких умов децентралізація владних повноважень, зокрема і в сфері регулювання земельних відносин, не має стати просто переданням повноважень у сфері земельних відносин із регіонального до територіального рівня. Беручи до уваги Ванкуверську декларацію щодо людських поселень 1976 року [12], земля є фундаментальним елементом поселень людей. Кожна держава має право вжити заходів щодо поширення публічного контролю на користування, володіння, розпорядження та охорону земель. Кожна держава має право планувати та регулювати використання землі як одного зі своїх найбільш важливих ресурсів таким чином, щоб зростання міських і сільських поселень базувався на всебічному плані використання земель. 
Відповідно до Концепції реформування місцевого самоврядування та територіальної організації влади в Україні громада має вирішувати, яким чином їй розпоряджатися землею - передати в оренду, віддати під приватизацію, дати дозвіл на спорудження підприємства (промислового, логістичного, рекреаційного) тощо [7].

Ухвалений 10 липня 2018 року за № 2498 Закон України «Про внесення змін до деяких законодавчих актів України щодо вирішення питання колективної власності на землю, удосконалення правил землекористування у масивах земель сільськогосподарського при, значення, запобігання рейдерству та стимулювання зрошення в Україні» набрав чинності з 1 січня 2019 року, однак уже зараз варто з ним детально ознайомитися для подальшої практичної реалізації його положень. У цьому Законі детально описано процедуру передання державної землі від Держгеокадастру до громад.

Слід зазначити, що всього в країні налічується понад 60 млн. га землі, 3 яких більше 70\% (42 млн. га) - землі сільськогосподарського призначення, які розташовані за межами населених пунктів. 3 них 27,5 млн. га розпайовані, ще 10,5 млн. га - державні. Й суттєва частина цих земель розташована в межах об'єднаних територіальних громад.

Уряд надав розпорядження Державній службі 3 питань геодезії, картографії та кадастру з 1 лютого 2018 року провести інвентаризацію земель 3 подальшим переданням земельних ділянок сільськогосподарського призначення державної власності в комунальну власність відповідних об’єднаних територіальних громад відповідно до статті 117 Земельного кодексу України [1]. Також передання земельних ділянок у користування (виключно через проведення аукціонів) або у власність буде здійснюватися тільки за погодженням з об’єднаними територіальними громадами та після ухвалення ними рішення відповідно до статті 26 Закону України «Про місцеве самоврядування в Україні» [9]. 
Завдяки ініціативі КМУ відтепер ОТГ будуть ухвалювати рішення, які мають сприяти розвитку сільськогосподарського виробництва, залученню інвестицій, суттєво збільшити надходження до місцевих бюджетів. Також децентралізація земельних відносин спрямована на подолання такої важливої проблеми, як подолання корупції в цій сфері. Рада громади сама визначає ставку земельного податку, 100\% якого буде залишатися в місцевому бюджеті.

Так, 2018 року бюджетні надходження об’єднаних громад від плати за землю зросли на 20\% - до 1,4 млрд. грн. Завдяки рішенню КМУ надходження зможуть суттєво збільшитись, адже в розпорядження об'єднаних територіальних громад може перейти до 7,2 млн. га, 3 яких 2,5 млн. га ще не розподілені між користувачами. Податкові надходження за використання земель, що містяться поза межами населених пунктів, можуть скласти до 10\% бюджетних надходжень ОТГ.

Сільськогосподарськими землями держави розпоряджався Держгеокадастр. Суттєва частина цих земель здавалася в оренду за найменшою орендною платою - 1-3\%, тобто за цінами, нижчими за ринкові, а об'єднані територіальні громади були повністю усунені від розпорядження такими земельними ділянками державної власності. Це збільшувало корупційні ризики, а громади недоотримували кошти на свій розвиток. Органи місцевого самоврядування фактично мали вплив лише на 12\% власних територій і були позбавлені можливостей ефективно планувати їх розвиток.

Проаналізувавши реформу та iï основні завдання, доцільно функцію здійснення контролю за використанням та охороною земель залишити на державному рівні й вона має здійснюватися органами виконавчої влади. Такі органи доцільно наділити значними контрольними повноваженнями, зокрема наприклад правом призупиняти рішення рад об’єднаних територіальних громад у сфері земельних відносин, які суперечать нормам національного законодавства, та звертатися до суду з вимогою про їх скасування. Місцеві 
громади мають право здійснювати самоврядний контроль за використанням земель у межах своїх територій, який проте не може підміняти собою контрольну функцію держави в розвитку земельних відносин.

Розглядаючи специфіку розвитку орендних відносин земель сільськогосподарського призначення в Україні, зазначимо, що подальший розвиток орендних земельних відносин має бути спрямований на захист прав орендодавців. На сьогодні можна стверджувати, що селяни недостатньо обізнані зі своїми правами стосовно оренди землі. Пасивність та необізнаність населення стосовно своїх прав є однією 3 основних причин невиконання орендарями договірних зобов'язань. У зв'язку з цим потрібно підвищувати рівень їх інформованості, активізувати роботу центрів юридичної допомоги та консалтингових служб, створювати спілки власників земельних паїв. Важливим $є$ налагодження громадського контролю за ефективним використанням земель через тісну співпрацю між власниками паїв, органами місцевого самоврядування й орендарями за рахунок створення спеціальних комісій, які будуть слідкувати за якісними показниками ділянки

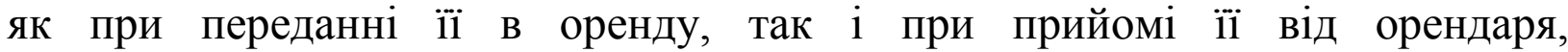
запобігатимуть рейдерському захопленню земель, наданих в оренду.

Висновки 3 дослідження. Ураховуючи вищезазначене, можна зробити висновок, що для роботи новостворених громад слід передати повноваження органам місцевого самоврядування 3 розпорядження земельними ресурсами державної власності з одночасним посиленням державного контролю над використанням та охороною земель. Децентралізація земельних відносин передбачає передання права розпорядження землями громадам, власність на землі переходить ОТГ, водночас повноваження Держгеокадастру мають бути розширені при здійсненні контролю за використанням землі. Новостворені об’єднані громади отримали потужні економічні ресурси для свого ефективного розвитку, водночас питання ефективного та раціонального користування земельним ресурсом ще й досі недостатньо врегульоване. 
Підсумовуючи вищенаведене, можна окреслити ключові напрямки вдосконалення державного регулювання процесів розвитку оренди земель в Україні, а саме:

- залучити до розроблення механізмів функціонування ринку земель фахівців аграрного напрямку та запровадити відповідну інфраструктуру цього ринку;

- на землі державної та комунальної власності продавати право оренди 3 метою отримання земельної ренти державою або територіальними громадами;

- запровадити вільний обіг земель приватної власності з накладенням мораторію на визначений термін для продажу землі іноземцям та особам із подвійним громадянством;

- визначити оптимальний розмір оренди землі сільськогосподарського призначення в одні руки, що не допустить монополізації на цьому ринку;

- продаж землі сільськогосподарського призначення або здання в оренду здійснювати лише через електронний аукціон, що забезпечить надходження до бюджетів відповідно до розроблених Податковим кодексом України норм.

Перспективи подальших розвідок. Відповідно до вищенаведеного в подальшому потрібно проаналізувати механізм проведення електронного аукціону в галузі продажу та орендування землі.

\section{СПИСОК ВИКОРИСТАНИХ ДЖЕРЕЛ:}

1. Земельний кодекс України: Закон України від 25.10.2001 № 2768-III URL: https://zakon.rada.gov.ua/laws/show/2768-14.

2. Малоокий В.А. Територіальні аспекти дослідження управління земельними ресурсами територіальних громад / B.A. Малоокий. URL: http://www.kbuapa.kharkov.ua/e,book/db/2016-1/ doc/2/10.pdf.

3. Данкевич В.Є. Розвиток земельних відносин в умовах глобалізації: [монографія] В.С. Данкевич. Житомир: О.О. Свенок, 2017. 392 с.

4. Дорош О.С. Управління земельними ресурсами на регіональному рівні / О.С. Дорош. К.: ЦЗРУ, 2004. 142 с. 6. Управління земельними ресурсами: [навч. посіб.] / За ред. A.M. Третяка.. Вінниця: Нова Книга, 2006. 360 с. URL: http://buklib.net/books/35323/ 
5. Управління земельними ресурсами: [навч. посіб.] / За ред. А.М. Третяка. Вінниця: Нова Книга, 2006. 360 c. URL: http://buklib.net/books/35323/

6. Конституція України від 28.06.1996 №254к/96-BP URL: https://zakon.rada.gov.ua/laws/show/254\%D0\%BA/96-\%D0\%B2\%D1\%80

7. Концепція реформування місцевого самоврядування та територіальної організації влади в Україні, схвалено розпорядженням КМУ від 01.04.2014 №333-p URL: https://zakon.rada.gov.ua/laws/show/333.2014.p

8. Закон України "Про добровільне об’єднання територіальних громад" від 05.02.2015 №157-VIII URL: https://zakon.rada.gov.ua/laws/show/ 157-19

9. Закон України "Про місцеве самоврядування в Україні" від 21.05.1997 №280/97-ВР URL: https://zakon.rada.gov.ua/laws/card/280/97-вр

10. Кулинич П.Ф. Децентралізація земельних повноважень органів влади: у пошуках оптимальної моделі // Вісник Укрдержреєстру. 2014. - №4.- С. 4-9.

11. Кулініч О. Запуск земельної децентралізації. час настав? / O. Кулініч URL: http://agravery.com/uk/posts/author/show?slug=zapuskzemelnoidecentralizaciicasnastav

12. The Vancouver Declaration On Human Settlements. URL: http://www.unhabitat.org/ campaigns/tenure/legal/van_dec.htm

13. Закон України "Про внесення змін до деяких законодавчих актів України щодо вирішення питання колективної власності на землю, удосконалення правил землекористування у масивах земель сільськогосподарського при, значення, запобігання рейдерству та стимулю, вання зрошення в Україні" 10 липня 2018 року за № 2498 URL: https://zakon.rada.gov.ua/laws/show/ 2498-19

\section{ANNOTATION}

Pronina Oksana. Associate Professor of the Department of State government and local government Kherson National Technical University Candidate of Sciences in Public Administration, Associate Professor

\section{RENTAL LAND MANAGEMENT AGRICULTURAL PURPOSE CONDITIONS OF DECENTRALIZATION IN UKRAINE}

The article deals with the main principles of land resources management in the context of decentralization of public administration and strengthening of the autonomy of local self-government bodies, their development on the basis of management of land resources which are located outside the settlements of the United Territorial Community, analyzes the main legislation and problems in this area.

The scientific and methodological and methodical principles of land management of the united territorial communities have been generalized and deepened. It has been proved that for territorial communities land resources are of 
value for two main reasons - as a component of the environment and local human habitation and as an economic resource for the organization of agricultural production. It points to the peculiarities of land resources that determine the state policy in the field of land relations. Such features are spatial limitations, naturalness and exhaustiveness of the resource, constancy of location, ability to deteriorate soil properties in case of mismanagement of land.

It is researched that the issues of decentralization of powers were reflected in the Concept of reforming of local self-government and territorial organization in Ukraine, which is connected with the fact that the bulk of land resources should be transferred to the disposal of local self-government bodies and united territorial communities, and the other part - leave under the state regulations. In doing so, state control over the use of land resources should be exercised by the State Geocadastr authority.

The opinion was formulated that only territorial communities should decide how to dispose of land, what should be the rate of land tax. This will be a serious tool for tackling corruption in land relations. The results of such innovations have ensured a growth of budget revenues by $20 \%$ or by 1.4 billion UAH in 2018 .

The newly formed united territorial communities have received powerful economic resources for their development, but the issue of efficient and rational using of land resources is still not sufficiently settled.

Key words: Land resources, agricultural lands, territorial community, decentralization, public administration.

\section{References:}

1. Zemel'nyy kodeks Ukrayiny: Zakon Ukrayiny vid 25.10.2001 № 2768-III URL: https://zakon.rada.gov.ua/laws/show/2768-14.

2. Malookyy V.A. Terytorial'ni aspekty doslidzhennya upravlinnya zemel'nymy resursamy terytorial'nykh hromad / V.A. Malookyy. URL: http://www.kbuapa.kharkov.ua/e,book/db/2016-1/ doc/2/10.pdf. 
3. Dankevych V.YE. Rozvytok zemel'nykh vidnosyn v umovakh hlobalizatsiyi: [monohrafiya] V.YE. Dankevych. Zhytomyr: O.O. Yevenok, 2017. 392 c.

4. Dorosh O.S. Upravlinnya zemel'nymy resursamy na rehional'nomu rivni / O.S. Dorosh. K.: TSZRU, 2004. 142 s. 6. Upravlinnya zemel'nymy resursamy: [navch. posib.] / Za red. A.M. Tretyaka.. Vinnytsya: Nova Knyha, 2006. 360 s. URL: http://buklib.net/books/35323/

5. Upravlinnya zemel'nymy resursamy: [navch. posib.] / Za red. A.M. Tretyaka. Vinnytsya: Nova Knyha, 2006. 360 s. URL: http://buklib.net/books/35323/

6. Konstytutsiya Ukrayiny vid 28.06.1996 №254k/96-VR URL: https://zakon.rada.gov.ua/laws/show/254\%D0\%BA/96-\%D0\%B2\%D1\%80

7. Kontseptsiya reformuvannya mistsevoho samovryaduvannya ta terytorial'noyi orhanizatsiyi vlady v Ukrayini, skhvaleno rozporyadzhennyam KMU vid 01.04.2014 №333-r URL: https://zakon.rada.gov.ua/laws/show/333.2014.r

8. Zakon Ukrayiny "Pro dobrovil'ne ob"yednannya terytorial'nykh hromad" vid 05.02.2015 №157-VIII URL: https://zakon.rada.gov.ua/laws/show/ 157-19

9. Zakon Ukrayiny "Pro mistseve samovryaduvannya v Ukrayini" vid 21.05.1997 №280/97-VR URL: https://zakon.rada.gov.ua/laws/card/280/97-vr

10. Kulynych P.F. Detsentralizatsiya zemel'nykh povnovazhen' orhaniv vlady: u poshukakh optymal'noyi modeli // Visnyk Ukrderzhreyestru. 2014. - №4.S. 4-9.

11. Kulinich O. Zapusk zemel'noyi detsentralizatsiyi. chas nastav? / O. Kulinich http://agravery.com/uk/posts/author/show?slug=zapuskzemelnoidecentralizaciicas nastav 
12. The Vancouver Declaration On Human Settlements. URL: http://www.unhabitat.org/ campaigns/tenure/legal/van_dec.htm

13. Zakon Ukrayiny "Pro vnesennya zmin do deyakykh zakonodavchykh aktiv Ukrayiny shchodo vyrishennya pytannya kolektyvnoyi vlasnosti na zemlyu, udoskonalennya pravyl zemlekorystuvannya u masyvakh zemel' sil's'kohospodars'koho pry, znachennya, zapobihannya reyderstvu ta stymulyu, vannya zroshennya v Ukrayini" 10 lypnya 2018 roku za № 2498 URL: https://zakon.rada.gov.ua/laws/show/ 2498-19 